\title{
PREPARATION, STRUCTURE AND CATALYTIC ACTIVITY OF SIMPLE SPINEL AS NANO-COPPER-ZINC FERRITES IN INDUSTRY MODEL
}

\author{
H. M. Awad 1,2,3, , and A. El-Maghraby ${ }^{3}$ \\ ${ }^{1}$ Department of Civil Engineering, College of Engineering, Taif University, KSA \\ ${ }^{2}$ Mining Studies and Research Unit, College of Engineering, Taif, KSA \\ ${ }^{3}$ Refractories, Ceramic and Building Materials Departments, National Research Center, Egypt \\ *E-mail : hma3011@yahoo.com
}

\begin{abstract}
The crystallized $\mathrm{Cu}_{1-\mathrm{x}} \mathrm{Zn}_{\mathrm{x}} \mathrm{Fe}_{2} \mathrm{O}_{4}$ ferrites nanocrystalline has been prepared at low-temperature combustion route to study as a novel friendly environmentally benign fuel. Five batches of spinel as $\mathrm{Cu}_{\mathrm{x}} \mathrm{Zn}_{1-\mathrm{x}} \mathrm{Fe}_{2} \mathrm{O}_{4}$ were synthesis by a self-combustion method using nitrates as salt. The phase composition, crystal intensity and the nanostructure characteristics were resolved by $\mathrm{x}$-ray diffraction and scanning electron microscope can be observations. BET analysis to indemnification the specific surface area around 20-10 nm. The results show an announced decrease in the combustion temperature when $\mathrm{Cu}$ - and $\mathrm{Zn}$ - ferrites spinel are utilized as catalysts effect. The ferrites have tested catalytically in combustion reaction of hydrogen peroxide.
\end{abstract}

Keywords: ferrite, catalyst, self-combustion, spinel, fuel materials.

() RASĀYAN. All rights reserved

\section{INTRODUCTION}

Ferrite materials are many scientific reports because of their prospect application in biology, ${ }^{1}$ electronics ${ }^{2}$ and catalysis ${ }^{3-4}$. The $\mathrm{Cu}_{1-\mathrm{x}} \mathrm{Zn}_{\mathrm{x}} \mathrm{Fe}_{2} \mathrm{O}_{4}$, where $0<\mathrm{x}>1$ at the tetrahedral location are taken by $\mathrm{Zn}^{2+}$ and $\mathrm{Fe}^{3+}$ cations and its spinel is indicated as partially inverse. The cation at a location in spinel structure is different properties such as magnetic and catalytic. The influence of temperature on ferrite formation and catalytic properties in the reaction of methanol decomposition has been researched for $\mathrm{ZnFe}_{2} \mathrm{O}_{4}$ crystal structure $^{5}$. It has been the size of crystallite well increases from $6 \mathrm{~nm}$ to $46 \mathrm{~nm}$ with increasing of synthesis temperature from $300{ }^{\circ} \mathrm{C}$ to $700{ }^{\circ} \mathrm{C}^{6-7}$. Some mixed ferrite materials exhibit increasable catalytic activity in methanol decomposition and the behavior of the catalytic ferrites well strongly depends on the stage transformations that take on by the effectiveness of the reaction ${ }^{8}$. The transition metal oxide catalysts are low efficient than noble metal catalysts but higher resistant to catalyst poisoning. Nanograined oxide compounds, called ferrites, offer new opportunities to promote the performances of solid catalysts ${ }^{9}$ in order to the fact the higher surface to bulk ratio liken to coarse micro-grained materials. Ferrites spinels are thermal and chemically stable ceramic materials with less cost and restful processing ${ }^{10}$. Many review and book have been reported ${ }^{11}$ giving a more comprehensive overview of the progress of combustion synthesis. The direct fabrications of materials, two techniques are reviewed, which have combustion synthesis with simultaneous densification and combustion synthesis casting ${ }^{12}$. The solutions based have been around for the synthesis of copper aluminate nanoparticles that include polymeric precursor method ${ }^{13}$, combustion ${ }^{14}$ and sol-gel method ${ }^{15}$. The gel-combustion synthesis is a time-and energy-saving and cost-effective strategy. These processes depend on the intimate mixing of suitable fuel such as glycine, urea or citric acid, metal nitrates in an aqueous solution a self- sustained and exothermic reaction between the fuel and oxidizers materials (i.e. nitrates). The effect of the amount of the fuel chosen and the $\mathrm{pH}$ of the precursor solution are factors in inhibiting selective precipitation and/or phase separation during the evaporation of solvents, which may be a change of the powder

Rasayan J. Chem., 11(3), 1320-1327(2018)

http://dx.doi.org/10.31788/RJC.2018.1133086

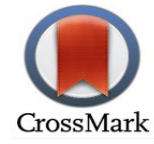


characteristics ${ }^{16}$. The aim of work is to prepare well-crystallized $\mathrm{Cu}_{1-\mathrm{x}} \mathrm{Zn}_{\mathrm{x}} \mathrm{Fe}_{2} \mathrm{O}_{4}$ ferrites with different composition and to test their catalytic behavior in hydrogen peroxide decomposition. The spinel has been synthesized at low-temperature combustion route employing L-alanine as a novel environmentally benign fuel.

\section{Material and Methods}

\section{EXPERIMENTAL}

Analytical-grade $\mathrm{Cu}\left(\mathrm{NO}_{3}\right)_{2}$ in BDH Company, $\mathrm{Zn}\left(\mathrm{NO}_{3}\right)_{2} .9 \mathrm{H}_{2}$ Oin Fluka Company, $\mathrm{Fe}\left(\mathrm{NO}_{3}\right)_{3} .9 \mathrm{H}_{2} \mathrm{Oin}$ BDH Company, L-alanine in Lab.Rasayan were applied as starting materials. The experimental materials at the compositions batches are recorded in Table-1. The aqueous solution containing $\mathrm{Cu}$ (II), $\mathrm{Zn}$ (II) and Fe (III) metal ion salts and fuel were heating at $60{ }^{\circ} \mathrm{C}$ with continuous stirring. After one hour, increase the heating temperature to 80 was studied. The aqueous solution was stirred as continuous for 2 hours to reach high viscous and the gel was formed.

\section{General Procedure}

The procedure followed in combustion synthesis consists in the preparation of an aqueous solution containing the starting materials under the proportion (Table-1). The spinel ferrites, $\mathrm{Cu}_{1-\mathrm{x}} \mathrm{Zn}_{\mathrm{x}} \mathrm{Fe}_{2} \mathrm{O}_{4}(\mathrm{X}=$ $0.1,0.3,0.5,0.8$ and 1 ) were intended by the self-combustion method by using metal nitrates and fuel as L-alanine were used.

Table-1: The Batches Composition of Pigment Spinel.

\begin{tabular}{l|l|l|l|l|l}
\hline \multicolumn{1}{c|}{ Batches } & \multicolumn{1}{c|}{ Symbols } & \multicolumn{1}{c|}{$\mathrm{Cu}\left(\mathrm{NO}_{3}\right)_{2}$} & \multicolumn{1}{|c|}{$\mathrm{Zn}\left(\mathrm{NO}_{3}\right)_{2} .9 \mathrm{H}_{2} \mathrm{O}$} & \multicolumn{1}{c}{$\mathrm{Fe}\left(\mathrm{NO}_{3}\right)_{3} .9 . \mathrm{H}_{2} \mathrm{O}$} & L-alanine \\
\hline $\mathrm{Cu}_{0.1} \mathrm{Zn}_{0.9} \mathrm{Fe}_{2} \mathrm{O}_{4}$ & CZFL1 & 1.56 & 17.33 & 52.30 & 28.81 \\
\hline $\mathrm{Cu}_{0.3} \mathrm{Zn}_{0.7} \mathrm{Fe}_{2} \mathrm{O}_{4}$ & CZFL2 & 4.73 & 13.58 & 52.68 & 29.01 \\
\hline $\mathrm{Cu}_{0.5} \mathrm{Zn}_{0.5} \mathrm{Fe}_{2} \mathrm{O}_{4}$ & CZFL3 & 7.93 & 9.77 & 53.07 & 29.23 \\
\hline $\mathrm{Cu}_{0.8} \mathrm{Zn}_{0.2} \mathrm{Fe}_{2} \mathrm{O}_{4}$ & CZFL4 & 12.84 & 3.95 & 53.66 & 29.55 \\
\hline $\mathrm{Cu} \mathrm{Fe}_{2} \mathrm{O}_{4}$ & CZFL5 & 16.17 & --- & 54.06 & 29.77 \\
\hline
\end{tabular}

The following procedures are the dissolution of metal nitrates in deionized water, L-alanine addition to the solution to make a colloidal solution and stirring at $60{ }^{\circ} \mathrm{C}$ after that drying the gel at $220^{\circ} \mathrm{C}$ and finally self-combustion. The dried gel was burned at the end by using a heated plate and an exothermic combustion reaction began. The combustion front spontaneously auto propagates and converts the dried gel into a loose powder. The scald powders were calcined at $500^{\circ} \mathrm{Cfor} 30 \mathrm{~min}$ to eliminate any residual organic compounds. The powders were heat treated at $700^{\circ} \mathrm{C}, 900^{\circ} \mathrm{C}$ and $1100^{\circ} \mathrm{C}$ for a short time of 10 minutes to obtain a good crystalline as a prepared powder.

\section{Detection Method}

X-ray diffraction (XRD) analysis was using an automated (Philips type: PW1840) diffract meter equipment with $\mathrm{Cu} \mathrm{K} \alpha$ radiation source. The particle size $\mathrm{T}$ was calculated by using an intense peak (311) use the Scherer formula. The particle size was carried out using a Scanning Electron Microscope. Differential thermal analysis (DTA) was a measurement with a coupled (SETARAM (SEM TG/DTA 92) DTA-TGA instrument. Morphology of the samples prepared was determined by scanning electron microscope). The samples were studied with a Philips®30 Analytical Scanning Electron Microscope. Particle images were obtained with a secondary electron detector. The CIE $L^{*} a^{*} b^{*}$ colorimetric method, recommended by the Commission Internationale de l'Eclairage (CIE) was pursued.

\section{XRD Analysis of the Fired Samples}

\section{RESULTS AND DISCUSSION}

The x-rays diffraction for copper ion as doping for $\mathrm{Cu}_{\mathrm{x}} \mathrm{Zn}$ (1-x) $\mathrm{Fe}_{2} \mathrm{O}_{4} \mathrm{u}$ sing L-alanine was studying. It is investigated as the fire powders at different heat treatment. The powders will start to form the crystalline at $700^{\circ} \mathrm{C}$ and the highest of the peaks increase by increase temperature at $900^{\circ} \mathrm{C}$ and $1100^{\circ} \mathrm{C}$ see in Fig. -1 . This identification peak is proportional to the substitution of $\mathrm{Zn}^{+2}$ ion by $\mathrm{Cu}{ }^{+2}$ ion. $\mathrm{Cu}_{x} \mathrm{Zn}_{1-x} \mathrm{Fe}_{2} \mathrm{O}_{4} \mathrm{crystal}$ forms prepared by solution combustion synthesis, exhibit different pale brown tones color shades in the 
sample. But, the brown yellow tones color intensifies from batches CZFL1 to CZFL5 as the substitution degree of $\mathrm{Zn}^{+2}$ by $\mathrm{Cu}^{+2}$ increases.

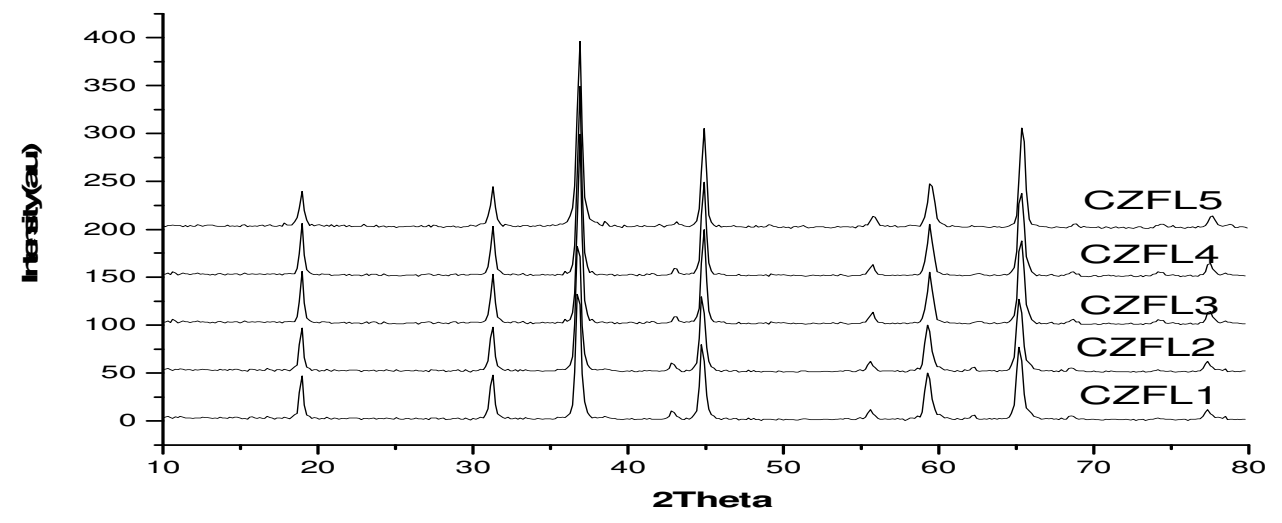

Fig.-1: X-Ray Diffraction Patterns of $\mathrm{Cu}_{\mathrm{x}} \mathrm{Zn}_{(1-\mathrm{x})} \mathrm{Fe}_{2} \mathrm{O}_{4}$

The crystallites size (D), the degree of strain (e) and lattice parameters determined from x-rays patterns are shown in Table-1. By measurement crystalline size, it is found the range from $43 \mathrm{~nm}$ to $60 \mathrm{~nm}$. The values for lattice constants were calculated for all the $\mathrm{Cu}_{\mathrm{x}} \mathrm{Zn}_{1-\mathrm{x}} \mathrm{Fe}_{2} \mathrm{O}_{4}$ nanoparticles using the characteristic and intense (311) peak from the x-ray pattern. The values of lattice constants are seen in Table-2 and plotted as see in Fig.-2. The lattice constant $\left(a^{\prime}\right)$ is constructing to decrease with increasing the copper concentration. The $\mathrm{Cu}^{2+}$ ions have a preference for the octahedral sites in structure and $\mathrm{Zn}^{2+}$ ions have a preference for the tetrahedral sites ${ }^{17}$.

\begin{tabular}{c|c|c|c}
\multicolumn{4}{c}{ Table-2: Lattice Constant Values } \\
\hline Composition & Conc. of $\mathrm{Cu}$ & Symbols & a Value A $^{0}$ \\
\hline $\mathrm{Cu} 0.1 \mathrm{Zn} 0.9 \mathrm{Fe} 2 \mathrm{O} 4$ & 0.1 & CZFL1 & 8.4380 \\
\hline $\mathrm{Cu} 0.3 \mathrm{Zn} 0.7 \mathrm{Fe} 2 \mathrm{O} 4$ & 0.3 & CZFL2 & 8.4271 \\
\hline $\mathrm{Cu} 0.5 \mathrm{Zn} 0.5 \mathrm{Fe} 2 \mathrm{O} 4$ & 0.5 & CZFL3 & 8.4045 \\
\hline $\mathrm{Cu} 0.8 \mathrm{Zn} 0.2 \mathrm{Fe} 2 \mathrm{O} 4$ & 0.8 & CZFL4 & 8.3912 \\
\hline $\mathrm{Cu} \mathrm{Fe} 2 \mathrm{O} 4$ & 1 & CZFL5 & 8.3044 \\
\hline
\end{tabular}

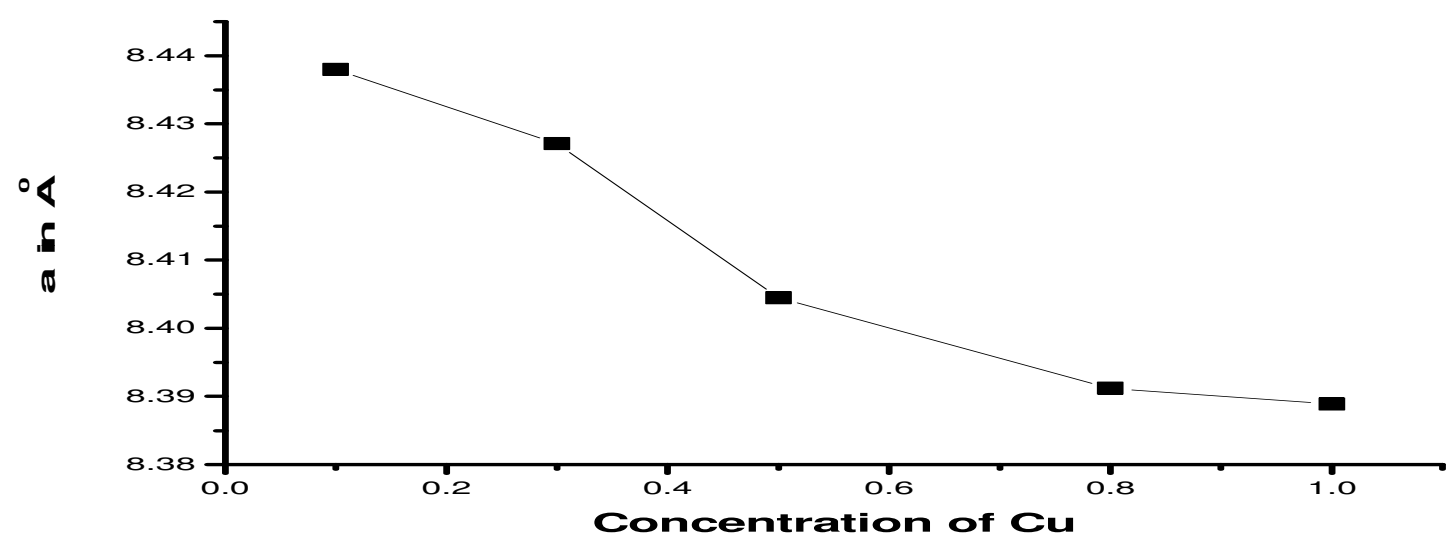

Fig.-2: Variation of Lattice Constant with Conc. of $\mathrm{Cu}$

The observed linear decrease of lattice constant with copper content $x$ can be assigned to the large ionic radius of $\mathrm{Zn}^{2+}\left(0.83 \mathrm{~A}^{0}\right)$ as liken to the ionic radius of $\mathrm{Cu}^{2+}\left(0.76 \mathrm{~A}^{0}\right)$. The smaller ionic radii $\mathrm{Cu}^{2+}$ replaces larger ionic radii $\mathrm{Zn}^{2+}$ and the lattice parameters shows decreasing trend with increasing copper content ${ }^{18}$. 
The x-ray density of the $\mathrm{Cu} \times \mathrm{Zn}(1-\mathrm{x}) \mathrm{Fe}_{2} \mathrm{O}_{4}$ ferrites spinel has been calculated from the molecular weight of the unit cell by using the equation:

$$
\rho \mathrm{x}=8 \mathrm{M} / \mathrm{Na}^{3}
$$

Where, 8 exemplify the number of molecules in a unit cell of spinel lattice, $M$ is molecular weight, $N$ is Avoga drops number and , $\mathrm{a}^{3}$ is lattice parameter. The values of $\mathrm{x}$-ray density $\rho \mathrm{x}$ are seeing in Table- 3 . From Table-3, we can see the x-ray density increases with increasing copper content in ferrite spinel. The increase in density of peaks in x-ray can be related with the lattice constant. In the present case of $\mathrm{Cu}-\mathrm{Zn}$ ferrites, the lattice constant decreases with the increased molecular weight and x-ray density increases with $\mathrm{Cu}$ content.

Table-3: Variation of X-Ray Density

\begin{tabular}{c|c|c|c}
\hline Composition & Symbols & Molar Ratio of $\mathrm{Cu}$ & X-Ray Density in g/cc \\
\hline $\mathrm{Cu} 0.1 \mathrm{Zn} 0.9 \mathrm{Fe} 2 \mathrm{O} 4$ & CZFL1 & 0.1 & 5.177 \\
\hline $\mathrm{Cu} 0.3 \mathrm{Zn} 0.7 \mathrm{Fe} 2 \mathrm{O} 4$ & CZFL2 & 0.3 & 5.201 \\
\hline $\mathrm{Cu} 0.5 \mathrm{Zn} 0.5 \mathrm{Fe} 2 \mathrm{O} 4$ & CZFL3 & 0.5 & 5.225 \\
\hline $\mathrm{Cu} 0.8 \mathrm{Zn} 0.2 \mathrm{Fe} 2 \mathrm{O} 4$ & CZFL4 & 0.8 & 5.272 \\
\hline $\mathrm{CuFe} 2 \mathrm{O} 4$ & CZFL5 & 1 & 5.291 \\
\hline
\end{tabular}

The crystallite/grain size of all the samples are calculated by measuring the full-width at half maximum (FWHM) of the characteristic peak (311) with the help of Scherer formula:

$$
\mathrm{T}=0.9 \lambda / \mathrm{Dp} \cos \theta
$$

Where, $\mathrm{T}$ is the crystalline size, $\lambda$ is the $\mathrm{x}$-ray wavelength, $\mathrm{Dp}$ the angular line width of half maximum intensity and $\theta$ is the Bragg angle in degrees. The particle size of $\mathrm{Cu}_{\mathrm{x}} \mathrm{Zn}_{(1-\mathrm{x})} \mathrm{Fe}_{2} \mathrm{O}_{4}(\mathrm{x}=0.1,0.3,0.5,0.8$ and 1) samples capitulates in Table-4, and it is seen that, the particle size $\mathrm{T}$ increases with increasing $\mathrm{Cu}$ content $x$ and is plotted as see in the Fig.-3.

Table-4: Particle Size of Samples

\begin{tabular}{c|c|c}
\hline $\mathrm{Cu} \times \mathrm{Zn}_{(1-\mathrm{x})} \mathrm{Fe}_{2} \mathrm{O}_{4}$ & Symbols & Particle Size (nm) \\
\hline $\mathrm{X}=0.1$ & CZFL1 & 15.1 \\
\hline $\mathrm{X}=0.3$ & CZFL2 & 17.2 \\
\hline $\mathrm{X}=0.5$ & CZFL3 & 18.2 \\
\hline $\mathrm{X}=0.8$ & CZFL4 & 20.4 \\
\hline $\mathrm{X}=1$ & CZFL5 & 22.1 \\
\hline
\end{tabular}

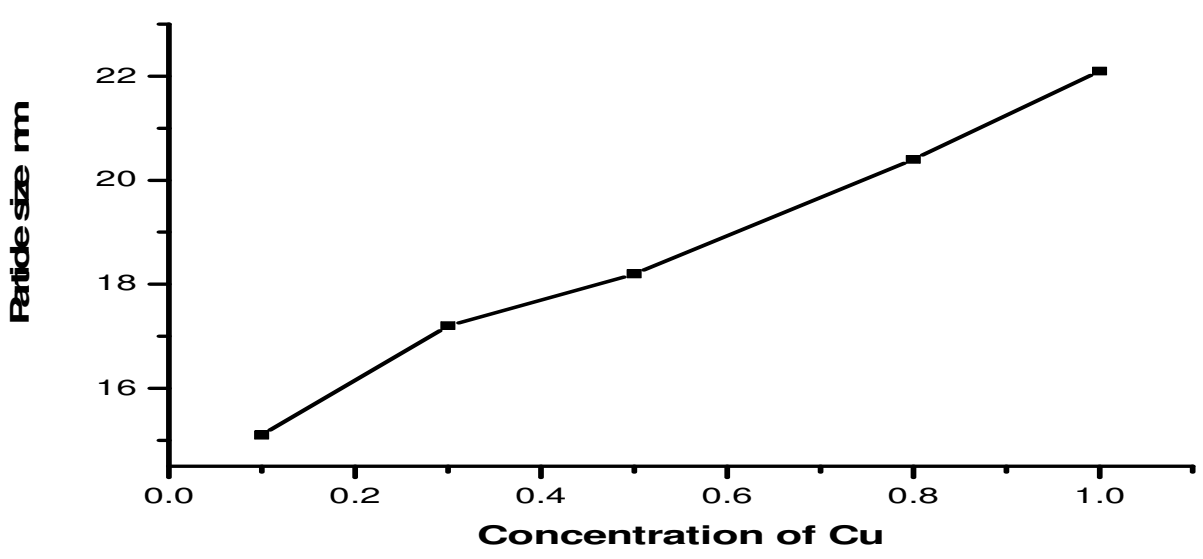

Fig.-3: Variation of Particle Sizes of Samples 


\section{Thermal Analysis}

The thermal analysis for 0.1 to $1 \mathrm{~mol}$ of $\mathrm{Cu}$ ion system using L-alanine gave several steps, as seen in the DTA curve for ash materials in Fig.-4. The DTA shows two endothermic steps at $498,555,740^{\circ} \mathrm{C}$ and 950 ${ }^{\circ} \mathrm{C}$. The endothermic step occurs for the elimination of the organic material in the green sample as carbon dioxide. The endothermic reaction as a peak at $880^{\circ} \mathrm{C}$ is a phase formation and appearance of phase. Since the combustion process takes place with maximum speed at $223^{\circ} \mathrm{C}$, ignition was achieved by a heating hotplate preheating at $200^{\circ} \mathrm{C}$. Thermal analyses shown in Fig.-4 indicate that the samples which suggest the end of the reduction/oxidation processes. The thermal change of the $\mathrm{Cux} \mathrm{ZnFe}_{2} \mathrm{O}_{4}$ systems ignited previously at $\sim 223{ }^{\circ} \mathrm{C}$ take place in degradation stages, as seen in the DTA/TG curve for ash materials in Fig.-4. The loss weight of the temperature $555{ }^{\circ} \mathrm{C}$ exemplifies the evolution of $\mathrm{CO}, \mathrm{CO}_{2}$ and $\mathrm{NO}_{\mathrm{x}}$ gases from sample then the solid ${ }^{19}$. A thermal decomposition study help to define the critical temperature required to synthesize the photocatalysts in order to possibly break down and loss of their activity by heating treatment ${ }^{20}$

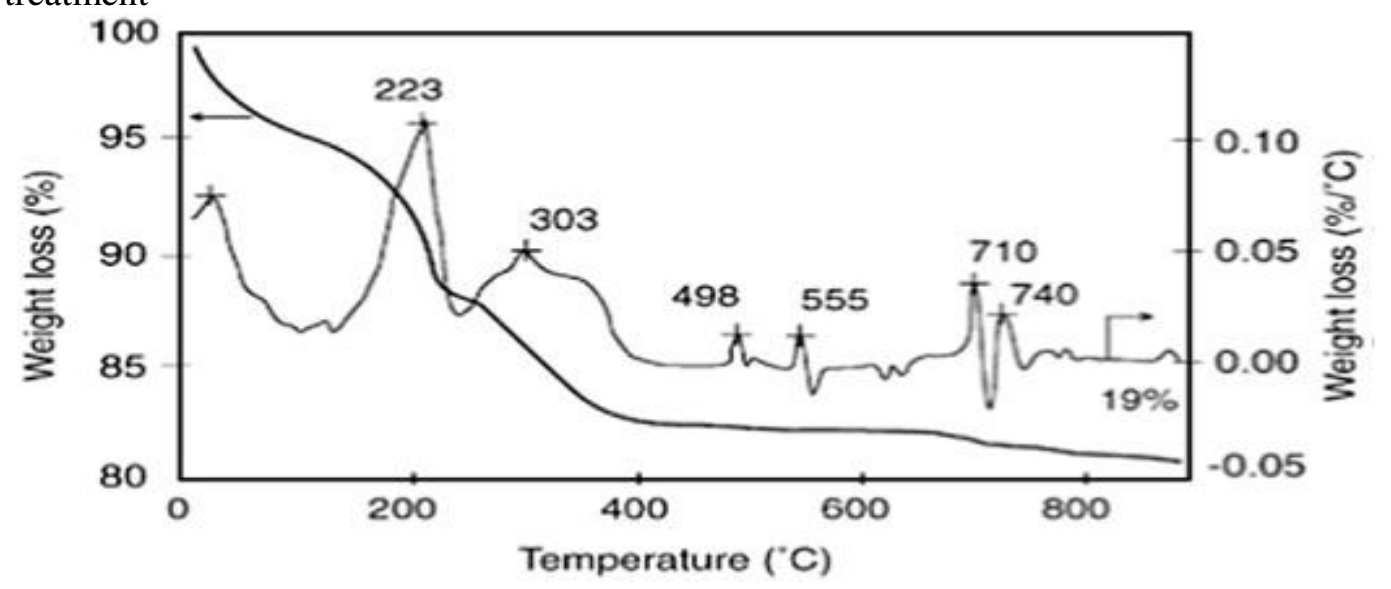

Fig.-4: TGA Spectrum of $\mathrm{ZnFe}_{2} \mathrm{O}_{4}$

For example, in preparing a composite photocatalyst of $\mathrm{CuZnFe}_{2} \mathrm{O}_{4}$, when calcined at $400{ }^{\circ} \mathrm{C}$ showed the ability to remove methyl orange dye from solution with $30 \%$ efficiency. When the temperature was increased up to $600{ }^{\circ} \mathrm{C}$ and not the removal of the dye propose that the photocatalyst was degraded by the heating process which to preferable to reduced activity.

\section{Ferrites as Catalytically by Hydrogen Peroxide}

The ferrite samples were utilized as heterogeneous catalysts to elevate the hydrogen peroxide decomposition, as:

$$
\mathrm{H}_{2} \mathrm{O}_{2} \rightarrow \mathrm{H}_{2} \mathrm{O}+0.5 \mathrm{O}_{2}
$$

The hydrogen peroxide decomposition is a changeful probe reaction used to discuss the effectiveness of heterogeneous systems towards the Fenton chemistry ${ }^{21}$. Results obtained from peroxide decomposition with different ferrites are seeing in Fig.-5.

The deterioration of the ratio ferrites plots exhibit a linear behavior ${ }^{21,22}$. The kinetic behavior has been seeing before for other ferrites, e.g. Based on this, it can be seen to said that the reaction has a pseudozeroth order dependence on the $\mathrm{H}_{2} \mathrm{O}_{2}$ concentration, $\mathrm{Vdec}=\mathrm{kdec}\left[\mathrm{H}_{2} \mathrm{O}_{2}\right]^{0}$. Hence, the reaction rates can be Prospect from the linear fit of the decomposition plots. The ferrites contain $\mathrm{Cu}$, as $\mathrm{Cu}-$, and $(\mathrm{Cu}$ $\mathrm{Zn}$ ) ferrites show high activity with constant reaction rates of $0.48,0.52$ and $0.72 \mathrm{mmol} \mathrm{min}^{-1}$ and the peroxide is consumed after 3 min of reaction. It is well confirmed in the literature that $\mathrm{Cu}^{2+}$ plays a function in the hydrogen peroxide decomposition ${ }^{23}$. The difference in the activity of the Cu-ferrite likens to that of $(\mathrm{Cu} \mathrm{Zn})$ and $(\mathrm{Cu})$ ferrites may be the presence of a higher concentration of $\mathrm{Cu}^{3+}$ on the $\mathrm{Cu}$ ferrite surface. The $\mathrm{Cu}$ ion in the $\mathrm{Zn}$-ferrite crystal increases the constant rate of $0.10 \mathrm{mmol} \mathrm{min}^{-1}$ and the $\mathrm{Cu}$-ferrite see a reaction rate of $0.18 \mathrm{mmol} \mathrm{min}^{-1}$. This activity of $\mathrm{Cu}$ containing ferrites can be demonstrated by the redox pair $\mathrm{Cu}^{+} / \mathrm{Cu}^{2+}$ at the surface ${ }^{24-29}$. 
RASĀYAN J. Chem.

Vol. 11 | No. 3 |1320 - 1327 | July - September | 2018

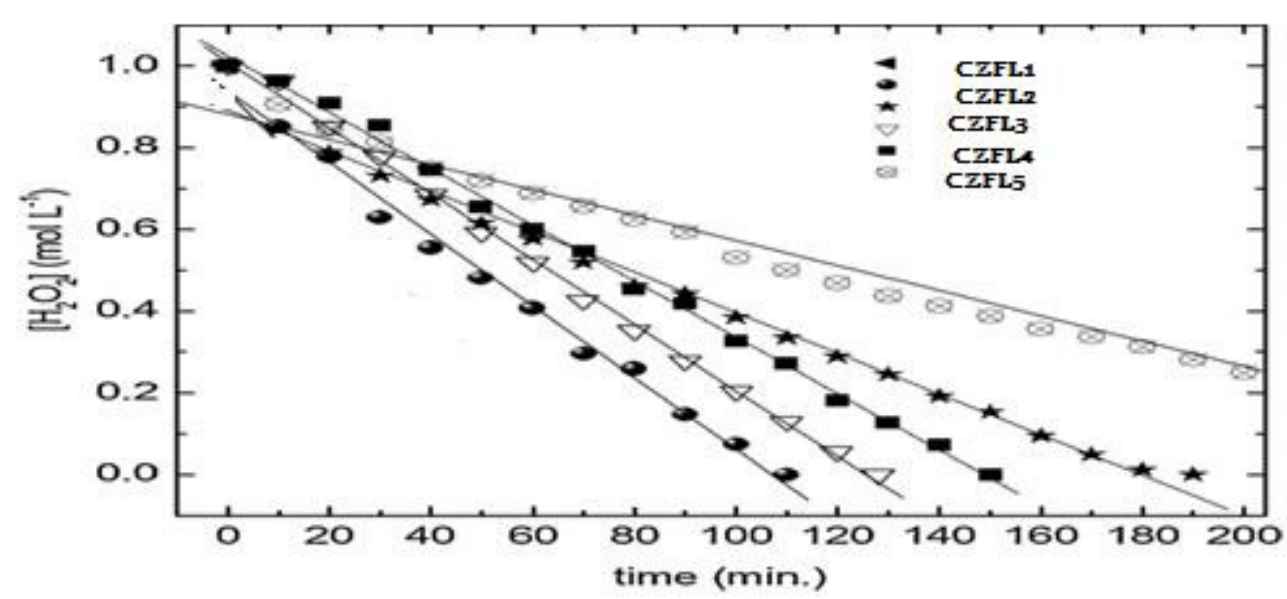

Fig.-5: Hydrogen Peroxide Decomposition in the Different Ratio Ferrites.

\section{Colored Measurements}

The CIE L* $\mathrm{a}^{*} \mathrm{~b}^{*}$ chromatic coordinates of powder samples and optimum parameters obtained in the optimization of ceramics samples are seen in Table (5). The samples CZFL1 to CZFL5 are grey and brown yellow colored because minimize $\mathrm{L}^{*} \mathrm{a} * \mathrm{~b} *$ parameters among all samples. Sample CZFL5 have a high percent of $\mathrm{Cu}$ and result in brown pigment. The sample CZFL1 gives the best pale grey colored sample minimizing $\mathrm{Cu}$ presence substituted by $\mathrm{Zn}$ in the spinel composition see in Fig.-7.

Table-5: L*a* b* Parameter and Tristimulus Values of $\mathrm{Cu}_{\mathrm{x}} \mathrm{Zn}_{(1-\mathrm{x})} \mathrm{Fe}_{2} \mathrm{O}_{4}$ Samples

\begin{tabular}{c|c|c|c|c|c|c|c|c}
\hline Samples & $\mathrm{L}^{*}$ & $\mathrm{a}^{*}$ & $\mathrm{~b}^{*}$ & $\mathrm{X}$ & $\mathrm{Y}$ & $\mathrm{Z}$ & $\mathrm{x}$ & $\mathrm{y}$ \\
\hline CZFL1 & 87.44 & -0.06 & -0.11 & 69.52 & 70.91 & 83.99 & 0.31 & 0.32 \\
\hline CZFL2 & 38.10 & 3.30 & 6.00 & 10.06 & 10.14 & 9.05 & 0.34 & 0.35 \\
\hline CZFL3 & 33.50 & 3.50 & 7.7 & 7.76 & 7.78 & 6.37 & 0.35 & 0.36 \\
\hline CZFL4 & 84.21 & -0.01 & 0.19 & 61.28 & 64.47 & 69.97 & 0.31 & 0.33 \\
\hline CZFL5 & 35.21 & 3.42 & 7.6 & 8.56 & 8.60 & 7.15 & 0.35 & 0.35 \\
\hline
\end{tabular}

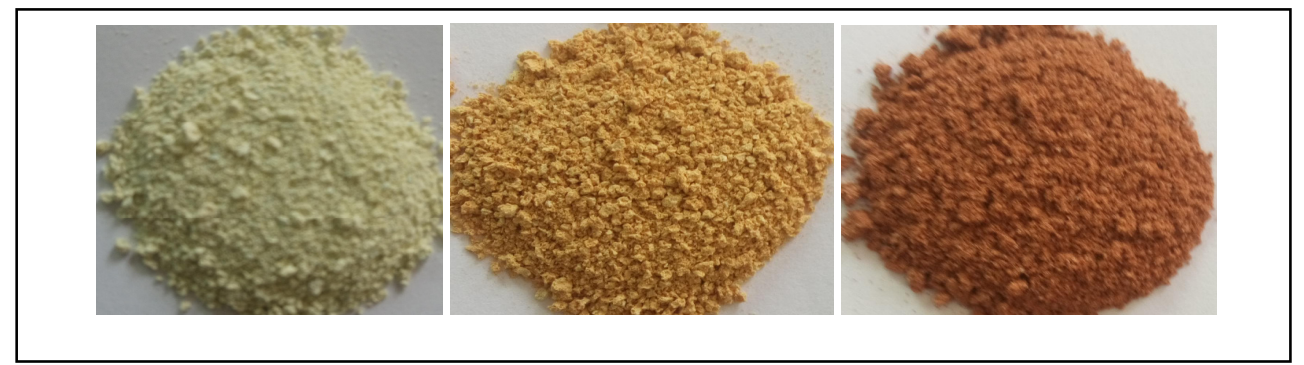

Fig.-7: The Color of Ferrite Spinel for 0.1, 0.5, and $1 \mathrm{~mol}$ of $\mathrm{Cu}^{+2}$

The evolution of (L) parameter of $\mathrm{Cu}^{+2}$ by $\mathrm{Zn}^{+2}$ substitutions in Table-5 shows a progressive decrease with the $\mathrm{Cu}^{+2}$ increases. The color degradation may be linked to the large specific surface area and small crystalline size of prepared by the solution combustion synthesis.

\section{Scanning Electron Microscopy}

Figure 8 shows SEM images of typical Cux $\mathrm{Zn}(1-\mathrm{x}) \mathrm{Fe}_{2} \mathrm{O}_{4}(x=0.1,0.5$ and 1$)$ nanoparticles. It can be seen in Fig. 8 at a ratio ( $x=0.1,0.5$ and 1), the microstructure of $\mathrm{Cu} \mathrm{Zn}$ ferrites reveal a uniform grain size has a homogeneous morphology and are equally distributed. The particle size increases with increasing $\mathrm{Cu}$ content in the crystal lattice in ferrite. The studies of micrographs of the fired powders have appeared that crystallization of the powder at $900{ }^{\circ} \mathrm{C}$ the spinel crystallizes completely with crystalline size of the order less than $20 \mathrm{~nm}$. 


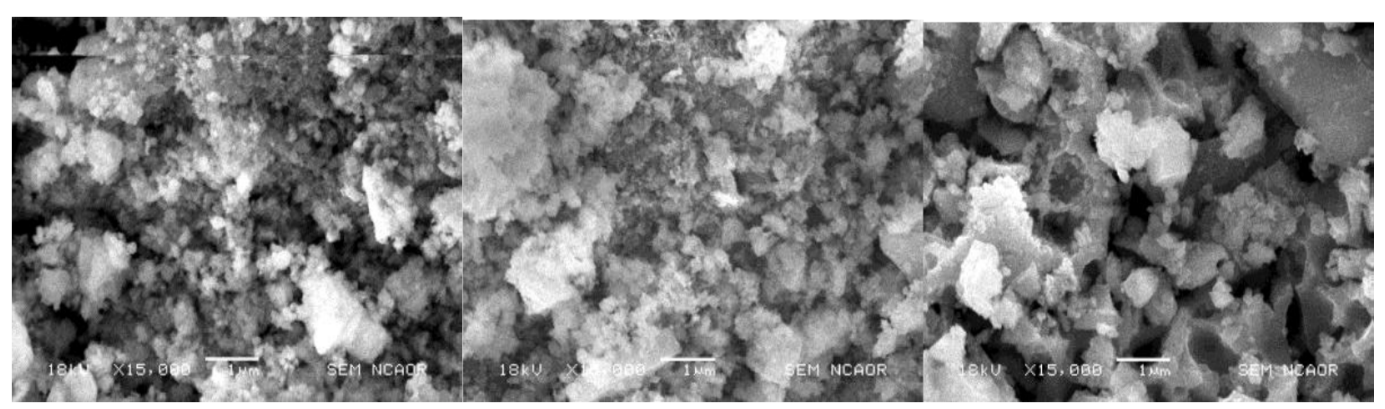

Fig.-8: Showing SEM Images Cux Zn (1-x) Fe2O4 ( $x=0.1,0.5$ and 1)

\section{CONCLUSION}

1. This method along with auto combustion technique has been successfully tried in series of nano particle $\mathrm{Cu}-\mathrm{Zn}$ ferrites.

2. The lattice constant decreased with an increase in copper content and the particle sizes were using Scherer formula and are found to be nano range.

3. The degradation at $520^{\circ} \mathrm{C}$ was accompanied to the loss of carbon dioxide.

4. The spinel crystallizes completely with a crystalline size less than $20 \mathrm{~nm}$.

5. The $\mathrm{Cu}$ ion in ferrites spinel is better performance in methylene blue oxidation and the ferrites are a promising potential nominee for the new materials.

\section{ACKNOWLEDGMENT}

This work was supported by grants from Vice President for Graduate Study and Research, Taif University, Saudi Arabia under project Grants No. 5541-438-1.

\section{REFERENCES}

1. K E. Scarberry, E. B. Dickerson, Z. J. Zhang, B. B. Benigno, J. F. McDonald, Nanomedicine: Nanotechnology, Biology, and Medicine, 6,399(2010), DOI: 10.1016/j.nano.2009.11.003

2. M. N. Ashiq, F. Naz, M. A. Malana, R. S. Gohar, Z. Ahmad, Mater. Res. Bull., 47, 683 (202), DOI: 10.1016/j.materresbull.2011.12.017

3. R. Benrabaa, H. Boukhlouf, S. Barama, E. Bordes- Richard, R. N. Vannier, A. Barama, Cat1al.Lett., 142, 42, (2012), DOI: 10.1007/ - s10562-0110726-8

4. A. S. Albuquerque, M. V.C. Tolentino, J. D. Ardisson, F. C. C. Moura, R. de Mendonc, W. A. A. Macedo, Ceram. Int., 38, 2225 (2012), DOI: 10.1016/j.ceramint.2011.10.071

5. K. Koleva, N. Velinov, T. Tsoncheva, I. Mitov, B. Kunev, Bulg. Chem. Commun., 45, 434(2013).

6. K. Koleva, N. Velinov, T. Tsoncheva, I. Mitov, Hyperfine Interact., 226, 89(2014), DOI: 10.1007/s10751-013-0966-7

7. K. V. Koleva, N. I. Velinov, T. S. Tsoncheva, I. G. Mitov, Bulg. Chem. Commun., 47(1), 348(2015).

8. M.S. Sadjadi, M. Mozaffari, M. Enhessari, K. Zare, Superlatices and Microstructures, 47, 685 (2010), DOI: $10.1016 /$ j.spmi.2010.02.007

9. N.L. Freitas, J.P. Continho, M.C. Silva, H.L. Lira, R.H.G.A. Kiminami, A.C.F.M. Costa, Materials Science Forum, 660, 943 (2010), DOI: 10.4028/www.scientific.net/MSF.660-661.943.

10. N. Rezlescu, E. Rezlescu, P.D. Popa, C. Doroftei, M. Ignat, Romanian Reports in Physics, 65(4),1348(2013).

11. L.Guanghua, L. Jiangtao, C. Kexin, A review, Int. Journal of Refractory Metals and Hard Materials 39, 90(2013), DOI: 10.1016/j.ijrmhm.2012.09.002

12. C. Ragupathi, J.JudithVijaya,n, L.JohnKennedy, M.Bououdina, Materials Science in Semiconductor Processing, 24,146(2014), DOI: 10.1016/j.mssp.2014.03.026

13. L. Gama, M. A. Ribeiro, B. S. Barros, R. H. A. Kiminami, I. T. Weber, A.C.F.M.Costa, J. Alloys Compd., 483, 453(2009), DOI: 10.1016/j.jallcom.2008.08.111. 
14. S. Chokkaram, R. Srinivasan, D. R. Milburn, B. H. Davis, J. Mol. Catal. A: Chem., 12, 157(1997), DOI: 10.1016/S1381-1169(97)00018-6

15. W. Li, J. Li, J. Guo, J. Eur. Ceram. Soc., 23, 2289(2003), DOI: 10.1016/S0955-2219(03)00081-5

16. Y. Zhanga, M. Wangb, Z. Leb, G. Huangb, L. Zoub, Z. Chenb, P, Ceramics International, 40, 5223(2014), DOI: 10.1016/j.ceramint.2013.10.09

17. H.M. Kazi, S. Choudhury, M.A. Hakim, International Nano Letters, 3,42(2013), DOI: 10.1186/2228-5326-3-42

18. W. Pan, F. Gu, K.Qi, Q. Liu, J. Wang, Mater. Chem. Phys., 134,1097(2012), DOI: 10.1016/j.matchemphys.2012.03.118

19. M.A. Valenzuela, P. Bosch, J. Jimenez-Becerrill, O. Quiroz, A.I. Paez, J. Photochem. Photobiol., A 148, 177(2002), DOI: 10.1016/S1010-6030(02)00040-0

20. S. Xu, D. Feng, W. Shangguan, J. Phys. Chem. C,113, 2463(2009), DOI: 10.1021/jp806704y

21. R.R.V.A. Rios, C.N. Silva, R.M. Lago, J. Hazard. Mater. B, 129, 171(2006), DOI: 10.1016/j.jhazmat.2005.08.028

22. R.C.C. Costa, F.C.C. Moura, J.D. Ardisson, J.D. Fabris, R.M. Lago, Appl. Catal. B, 83, 131(2008), DOI: $10.1016 /$ j.apcatb.2008.01.039

23. F.C.C. Moura, M.H. Araujo, J.D. Ardisson, W.A.A. Macedo, A.S. Albuquerque, R.M. Lago, J. Braz. Chem. Soc., 18, 322(2007), DOI: 10.1590/S0103-50532007000020012

24. P. Baldrian, V. Merhautova', J. Gabriel, F. Nerud, P. Stopka, M. Hruby', M.J. Benes, Appl. Catal. B, 66, 258(2006), DOI: 10.1016/j.apcatb.2006.04.001

25. A. Sabarudin, R. Wahid, F.C. Nalle, R.A. Shobirin and D.J.D.H. Santjojo , Rasayan J. Chem., 10(4), 1261(2017), DOI: 10.7324/RJC.2017.1041906

26. I. O. Wulandari, D. J. D. H Santjojo, R. A. Shobirin and A. Sabarudin, Rasayan J. Chem., 10(4), 1348(2017), DOI: 10.7324/RJC.2017.1041907

27. G. Rajashekhar, Rizwana, and P. Sarah, Rasayan J. Chem., 11(1), 361(2018), DOI: 10.7324/RJC.2018.1112057

28. V. M. Shevko, A. D. Badikova, D. D. Amanov, G. E. Karataeva and B. A. Lavrov, Rasayan J. Chem., 11(3), 1050(2018), DOI: 10.31788/RJC.2018.1132038

29. T. Kamakshi1, G. Sunita Sundari, Harikrishna Erothu, and T. P. Rao1 Rasayan J. Chem., 11(3), 1113(2018), DOI: 10.31788/RJC.2018.1134003

[RJC-3086/2018] 